\title{
EFEKTIFITAS PENGGUNAAN PROGRAM SEASI UNTUK MENCEGAH HIPERTENSI DIDESA GUDANG HIRANG RT.10 KABUPATEN BANJAR
}

\author{
Eirene E.M.Gaghauna ${ }^{1^{*}}$,Bagus Rahmat Santoso ${ }^{2}$ \\ 1,2 Jurusan Keperawatan, Fakultas Kesehatan Universitas Sari Mulia \\ *email: eirenegaghauna@gmail.com
}

\begin{abstract}
ABSTRAK
Proses penuaan adalah salah satu proses dalam kehidupan manusia dimana terjadi perubahan progresif, yang menyebabkan berbagai penurunan fungsi organ-organ tubuh pada manusia. Salah satunya penurunan fungsi organ kardiovaskular yang ditandai dengan penyakit darah tinggi (hipertensi) pada lansia. Tekanan darah tinggi (hipertensi) adalah suatu kondisi dimana tekanan darah terus menerus meningkat yang merupakan masalah kesehatan global karena prevalensinya yang tinggi di seluruh dunia. Data World Health Organization (WHO) tahun 2015 menunjukkan sekitar 1,13 Miliar orang di dunia menyandang hipertensi, artinya 1 dari 3 orang di dunia terdiagnosis hipertensi. Jumlah penyandang hipertensi terus meningkat setiap tahunnya, diperkirakan pada tahun 2025 akan ada 1,5 Miliar orang yang terkena hipertensi, dan diperkirakan setiap tahunnya 10,44 juta orang meninggal akibat hipertensi dan komplikasinya.Tai chi merupakan terapi komplementer melalui konektivitas antara body-mind-spirit dari setiap individu, latihan yang memadukan antara gerakan fisik yang lambat, pernafasan, perasaan, dan pikiran dalam suatu kesatuan sehingga terdapat keseimbangan antara fisik, mental, emosional, dan spiritual.Solusi yang diharapkan dengan dilakukannya senam Tai chi pada masyarakat dapat mengurangi angka kejadian hipertensi pada lansia.
\end{abstract}

Kata kunci : masyarakat, Hipertensi, Tai chi

\section{A. PENDAhULUAN}

Proses penuaan adalah salah satu proses dalam kehidupan manusia dimana terjadi perubahan progresif, yang menyebabkan berbagai penurunan fungsi organorgan tubuh pada manusia. Salah satunya penurunan fungsi organ kardiovaskular yang ditandai dengan penyakit darahA tinggi (hipertensi) pada lansia. Tekanan darah tinggi (hipertensi) adalah suatu kondisi dimana tekanan darah terus menerus meningkat yang merupakan masalah kesehatan global karena prevalensinya yang tinggi di seluruh dunia. Data World Health Organization (WHO) tahun 2015 menunjukkan sekitar 1,13 Miliar orang di dunia menyandang hipertensi, artinya 1 dari 3 orang di dunia terdiagnosis hipertensi. Jumlah penyandang hipertensi terus meningkat setiap tahunnya, diperkirakan pada tahun 2025 akan 
ada 1,5 Miliar orang yang terkena hipertensi, dan diperkirakan setiap tahunnya 10,44 juta orang meninggal akibat hipertensi dan komplikasinya.Demografi wilayah masyarakat bertempat di Jalan Martapura Lama km. 11,500 RT.10, Desa Gudang Hirang, Kecamatan Sungai Tabuk, Kabupaten Banjar, Kalimantan Selatan. Luas lahan persawahan yang ada di Desa Gudang Hirang sebesar 848 Ha dan luas sungainya sebesar $3 \mathrm{Ha}$. Batas wilayah RT.10 ini sekitar $300 \mathrm{~m}^{2} \mathrm{ke}$ arah Sungai Lulut dan $300 \mathrm{~m}^{2} \mathrm{ke}$ arah Sungai Tabuk. Sumber mata pencaharian penduduk di Desa Gudang Hirang sebagian besar adalah petani yaitu sebanyak 744 orang, dan sisanya bekerja sebagai pedagang, PNS, tukang, buruh harian lepas, wiraswasta, sopir, dan lainlain. Masyarakat di Desa Gudang Hirang memiliki tingkat pendidikan paling banyak adalah tamatan
Sekolah Dasar (SD)/Sederajat sebanyak 2.145 orang.

Jumlah penduduk di RT. 10 sekitar 425 orang terdiri dari 168 Kepala Keluarga dengan mata pencaharian sebagian besar adalah petani. Nilai kebudayaan di masyarakat Desa Gudang Hirang khususnya di RT.10 sangat baik karena selalu rutin mengadakan kegiatan keagamaan setiap Jum'at di masjid. Berdasarkan observasi masyarakat desa Gudang Hirang RT 10 Kabupaten Banjar adalah:

1. Tingginya angka penderita Hipertensi di RT 10

2. Kurangnya pengetahuan masyarakat dalam mencegah komplikasi dari penyakit.

3. Kurangnya kesadaran masyarakat tentang pentingnya pemeriksaan kesehatan

4. Kurangnya kesadaran masyarakat terhadap pentingnya menjaga pola hidup sehat

Gambar 1.1 Pemberian Materi tentang Hipertensi dan pentingnya Senam Anti Hipertensi

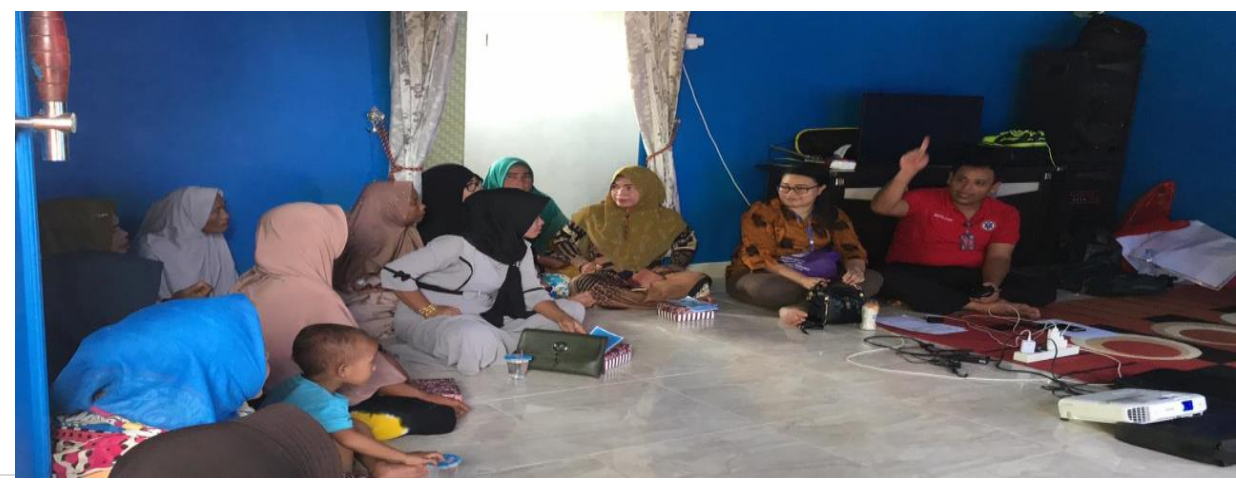




\section{Gambar 1.2 Pelaksanaan Program SEASI}

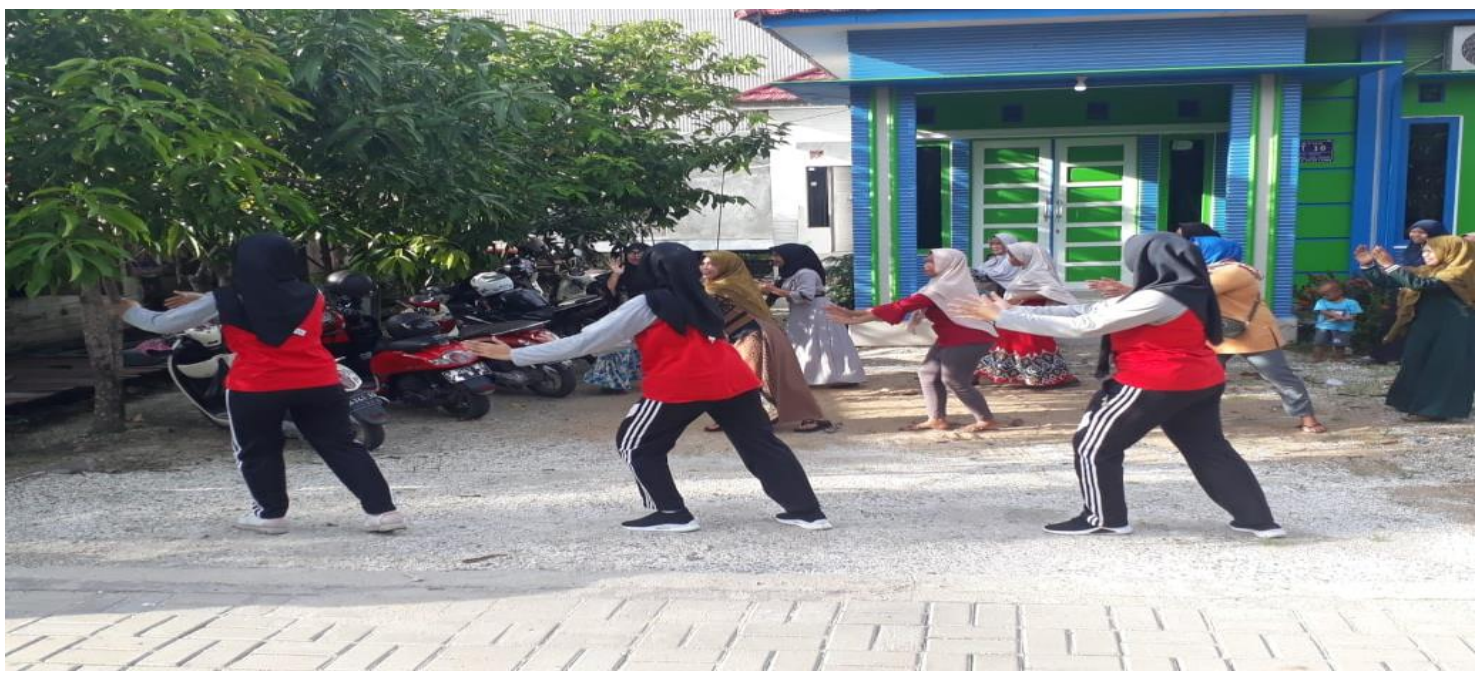

\section{B. METODE}

Metode pemecahan masalah yang sesuai adalah dengan pendekatan community development. Pengabdi bekerjasama dengan anggota masyarakat untuk melaksanakan program pengabdian. Program pengabdian yang dilakukan melalui 3 tahapan yaitu tapah persiapan, tahap pelaksanaan dan tahap evaluasi.

Tahap persiapan dimulai dengan Survey dilakukan di wilayah desa Gudang Hirang RT 10 dengan di dampingi oleh Ketua RT setempat. Setelah dilakukannya observasi dan pengumpulan data menggunakan kuesioner dengan warga desa setempat, kami menemukan bahwa terdapat 17 orang penderita hipertensi sehingga perlu dilakukannya edukasi kesehatan dan melakukan senam anti hipertensi untuk mencegah terjadinya komplikasi sehingga dapat meningkatkan status kesehatan masyakat di wilayah tersebut. Kami melakukan perijinan pada ketua RT 10 Desa Gudang Hirang.

Pelaksanaan kegiatan dilakukan pada tanggal 25 Agustus'2021, pukul 15.00 WITA. Pelaksanaan kegiatan dijalankan bekerjasama dengan anggota kelompok. Tahap evaluasi dilaksanakan pada bulan ke 3 (20 Oktober'2021). Tahap evaluasi ini dilakukan Pemantauan bekerja sama dengan ketua RT 10, melakukan kunjungan ulang setelah 1 bulan kegiatan Penyuluhan Kesehatan dan dilakukan wawancara singkat kepada 


$\begin{array}{lrr}\text { masyarakat } & \text { yang } & \text { pernah } \\ \text { mendapatkan } & \text { materi } & \text { penyuluhan } \\ \text { kesehatan } & \text { tentang } & \text { Penyakit } \\ \text { Hipertensi. } & & \end{array}$

\section{HASIL DAN PEMBAHASAN}

Pendidikan Kesehatan Kepada Masyarakat terbagi menjadi 3 tahap yaitu tahap awal analisis situasi dan kondisi, melakukan pendidikan kesehatan, monev/monitoring dan evaluasi. Permasalahan yang didapatkan di Desa Gudang Hirang RT 10 setelah melakukan analisis situasi lapangan yaitu banyaknya masyarakat yang memiliki penyakit hipertensi. Masyarakat kurang mendapatkan penyuluhan kesehatan tentang hipertensi dan juga jarang melakukan pemeriksaan tekanan darah. Selama ini masyarakat hanya mengetahui secara umum saja dan tidak mengetahui banyak tentang apa itu hipertensi dan bagaimana pencegahannya.

Penyuluhan kesehatan tentang" Efektivitas Program SEASI untuk mencegah komplikasi Hipertensi " di Desa Gudang Hirang RT 10 salah satu upaya untuk meningkatkan pengetahuan masyarakat tentang kesehatan, sebagai tahap kedua kegiatan pengabdian kepada masyarakat kemudian melakukan follow up dan dilanjutkan dengan evaluasi. Rincian kegiatan berupa persiapan, penyuluhan dan melakukan kegiatan senam hipertensi di Desa Gudang Hirang RT 10.

Tahap-tahap penyuluhan kesehatan di Desa Gudang Hirang RT 10 yaitu Tahap pertama penyelenggara menyiapkan spanduk (banner), leaflet, tahap kedua panitia memberikan materi penyuluhan kepada masyarakat, tahap ketiga kegiatan dilaksanakan akan dilakukan Tanya jawab mengenai topik yang dibawakan dan setelah itu dilakukan kegiatan senam anti hipertensi atau senam tai chi.

Adanya penyuluhan kesehatan di desa tersebut masyarakat mampu mengetahui terkait Penyakit Hipertensi, yaitu cara mencegah, cara mengobati dan mengetahui faktor risiko terjadinya penyakit hipertensi, dan setelah di lakukannya penyuluhan kesehatan masyarakat dapat menerapkan ilmu yang telah disampaikan dan mereka dapat mencegah agar tidak terjadinya 
komplikasi serta menambah penyakit menjadi tambah parah.

Kegiatan ini sangat membantu dalam menambah pengetahuan masyarakat tentang "Hipertensi”. Setelah kegiatan penyuluhan kesehatan, lalu dilakukan monev/monitoring selama 1 bulan kemudian sebagai bentuk menindak lanjuti terhadap perubahanikap dan perilaku masyarakat. Pemantauan bekerja sama dengan ketua RT 10, melakukan kunjungan ulang setelah 1 bulan kegiatan Penyuluhan Kesehatan dan dilakukan wawancara singkat kepada masyarakat yang pernah mendapatkan materi penyuluhan kesehatan tentang Penyakit Hipertensi.

\section{KESIMPULAN}

Hipertensi adalah peningkatan tekanan darah sistolik dan diastolik yang melebihi batas normal yaitu sistolik diatas $140 \mathrm{mmHg}$ dan diastolik diatas $90 \mathrm{mmHg}$ (Nur, 2016). Promosi kesehatan dan

\section{DAFTAR PUSTAKA}

Amirudin, Wahyuddin, 2014, Studi Kasus Kontrol Faktor Biomedis Terhadap Kejadian Hipertensi Ibu di Puskesmas Bantimurung pencegahan Hipertensi kepada warga RT 10 desa Gudang Hirang adalah salah satu metode untuk memberikan pengetahuan kepada masyarakat. Permasalahan yang muncul pada warga berdasarkan kuisiuner yang dibagikan adalah tingginya angka penderita hipertensi di desa tersebut sehingga diperlukan adanya promosi kesehatan untuk mencegah terjadinya komplikasi penyakit tersebut.

Solusi dari permasalahan yang terjadi adalah dengan menjalankan program SEASI (Senam Anti Hipetensi) yang dilakukan di RT 10 desa Gudang Hirang sehingga masyarakat sadar akan pentingnya melakukan aktivitas fisik berupa senam untuk mencegah komplikasi dari penyakit hipertensi. Kegiatan ini diikuti oleh masyarakat sekitar di RT 10 desa Gudang Hirang dapat meningkatkan pengetahuan, pemahaman dan pencegahan komplikasi penyakit hipertensi yang dialami masyarakat desa tersebut.
Maros, Jurnal Medika Nusantara. Vol. 25 No. 2.

Marianti, A.C.N. (2016). Hypertension Management Approach Through 
Modifiable Risk Factors in Jember Region Community Health Center. Proceeding ICMHS 2016

Nurjanah. (2012).Hubungan Antara Paritas dan Umur dengan Hipertensi Tahun 2012. Semarang: Universitas Muhammadiyah Semarang.

Salmariantity. (2012). Faktor- faktor yang Berhubungan dengan Hipertensi di Wilayah Kerja Puskesmas Gajah Mada Tembilahan Kabupaten Indragiri Hilir tahun 2012. Jakarta: FK UI.

Utami, A.T., Assegaf, A.A.R., Silahudin, F., et.al. (2020). The effect of gym and zikr towards reduction blood pressure among elderly in suburban Malang city, Indonesia. Journal of Orthopaedic Disolders Reports. 3(1).

Wardiah, A., et all. (2013). Faktor-faktor yang mempengaruhi kejadian hipertensi di wilayah kerja Puskesmas Sekampung Kabupaten Lampung Timur tahun 2013. Bandarlampung: PSIK Universitas Malahayati. 